\title{
Milk-substitute diet composition and abomasal secretion in the calf
}

\author{
By V. J. WILLIAMS*, J. H. B. ROY AND CATHERINE M. GILLIES \\ National Institute for Research in Dairying, Shinfield, Reading $R G 2{ }_{9} A T$ \\ (Received 30 October 1975 - Accepted I 5 April г976)
}

1. The effect of different protein sources in milk-substitute diets on abomasal acidity and proteolytic activity was studied in Friesian calves, aged $20-58 \mathrm{~d}$ (Expt 1 ). The diets contained ' mildly' preheated, spray-dried skim-milk powder (MHM), 'severely' preheated, spray-dried skim-milk powder (SHM), fish-protein concentrate (FPC) or solvent-extracted soya-bean flour (SF) as the main protein source.

2. Gastric juice was collected from abomasal pouches before feeding and at $\mathbf{I}_{5} \mathrm{~min}$ intervals for $8 \mathrm{~h}$ after the morning feed. Samples of digesta were obtained from the abomasum at $\mathrm{I} h$ intervals during the same period.

3. Digesta $\mathrm{pH}$ was lower and titratable acidity higher $0-3 \mathrm{~h}$ after giving the diet containing MHM than when any of the other three diets was given.

4. Acid secretion from the pouches for the different diets was in the order: FPC > MHM $>\mathrm{SHM} \geqslant \mathrm{SF}$.

5. Protease secretion from the pouches, assayed at $\mathrm{pH} 2 \cdot 1$, was in the order: MHM > $\mathrm{SHM}=\mathrm{FPC}>\mathrm{SF}$.

6. The effect of dry matter (DM) intake and concentration on abomasal acidity was also studied in calves given diets which contained MHM (Expt 2). This diet was reconstituted at either 100 or $149 \mathrm{~g} \mathrm{DM} / \mathrm{kg}$ liquid diet and fed at either 32.5 or $49^{\circ} \circ \mathrm{g} \mathrm{DM} / \mathrm{kg}$ live weight ${ }^{0.75}$ per d. Samples of abomasal digesta were collected as in Expt $\mathrm{I}$.

7. A high intake of DM at a low DM concentration resulted in low acidity of the digesta in the first $3 \mathrm{~h}$ after feeding, which suggested a dilution effect. Comparison of two diets of different DM concentration, which were fed in the same volume of liquid, indicated that the greater the DM intake, the greater was the amount of acid secreted.

8. It is concluded that the protein sources varied in their ability to stimulate abomasal acid and protease secretion and it is suggested that this may relate to calf performance.

There are indications that abomasal secretory activity may be low when calves are given milk-substitute diets containing 'severely' preheated skim-milk powder (SHM) or soya-bean flour (SF) as protein sources, and this may be associated with a high incidence of digestive disorder at a young age (Shillam, Roy \& Ingram, I962; Tagari \& Roy, I969; Ternouth, Roy \& Siddons, I974; Ternouth, Roy, Thompson, Toothill, Gillies \& Edwards-Webb, 1975). As the evidence is indirect, acid and protease secretion evoked by various protein sources fed to calves with gastric pouches has been studied. The effect of concentration and level of intake of dry matter (DM) on the acidity of abomasal digesta was also studied, as were the effects of time after feeding and age on the secretory activity of the pouches.

\section{EXPERIMENTAL}

\section{Experimental design}

Abomasal secretory activity in calves was assessed by the measurement of $\mathrm{pH}$, total titratable acidity and proteolytic activity at $\mathrm{pH} 2 \cdot \mathrm{I}$ (pepsin $\left(E C \mathrm{~B}_{3} .4 .23 .1\right)$ activity)

* Present address: Department of Physiology, University of New England, Armidale, New South Wales 235 I, Australia. 
and at $\mathrm{pH} 3.5$ (rennin $(E C 3.4 .23 .4)$ activity) in fundic pouch secretion and by the measurement of $\mathrm{pH}$ and total titratable acidity of abomasal digesta.

Two experiments were made, the design of each being a balanced $4 \times 4$ Latin square. This design was selected because of the necessity to compare treatments over a short period of the calf's life and because the number of calves that could be surgically prepared was small.

In Expt I, the effects on abomasal secretory activity of four protein sources were compared. 'These were: 'mildly' preheated, spray-dried skim-milk powder (MHM), SHM ('severely' preheated, spray-dried skim-milk powder), fish protein concentrate (FPC) and SF (soya-bean flour). Experimental periods usually lasted $6 \mathrm{~d}$. Each period was preceded and succeeded by a $4 \mathrm{~d}$ period in which a control diet, based on milk protein, was fed to allow a study of the effect of age on abomasal pouch secretion.

In Expt 2, the diets were based on milk protein. Two dietary concentrations of $\mathrm{DM}, \mathrm{I} 00$ and $\mathrm{I} 49 \mathrm{~g} / \mathrm{kg}$ liquid diet (designated Io and ${ }_{5}$ respectively) at two levels of DM intake ( $\mathrm{L}$ and $\mathrm{H}$ ) were compared for their effects on abomasal secretory activity. The experimental periods were usually $6 \mathrm{~d}$. For most calves only their abomasal digesta was studied, because their fundic pouches had deteriorated.

\section{Calves}

Unsuckled Friesian bull calves were used and were given $7 \mathrm{~kg}$ colostrum during the first $2 \mathrm{~d}$ of life; thereafter, the calves received the control diet until the beginning of the experiment. Calves $4,6,7$ and 8 were randomly assigned to the sequence of treatments in Expt I and calves I, 3, 4 and 9 were used in Expt 2. The age of calves at the beginning of Expt I was $17^{-26} \mathrm{~d}$.

\section{Diets}

The composition of the milk-substitute diets is given in Table I.

Control diet. The DM of this diet contained $(\mathrm{g} / \mathrm{kg}): 800 \mathrm{MHM}, \mathrm{r} 30$ tallow, 60 coconut oil, Io lecithin, and a mineral and vitamin supplement containing calcium, phosphorus, magnesium, iron, copper, cobalt, zinc, manganese, iodine, retinol, cholecalciferol, $\alpha$-tocopherol and cyanocobalamin. The diet, which was compounded and supplied as a powder (Volac Ltd, Royston, Herts.), was reconstituted with water to contain $\mathrm{I} / 4 \mathrm{~g} \mathrm{DM} / \mathrm{kg}$ liquid diet.

Experimentalmilk-substitute diets. The hexane-extracted SF (Sorbasoy Special; British Arkady Co. Ltd, Manchester) had been treated by a thermo-alkali method to destroy bound trypsin inhibitor. To ensure that the four diets were similar in protein and in carbohydrate content, spray-dried whey powder (Krafco; Kraft Foods Ltd, London NWI) was included in the diets containing FPC and SF. For the diet containing SHM, the preheating treatment during spray-drying denatured a high proportion of the whey proteins resulting in a reduction in the non-casein- $\mathrm{N}$ as a percentage of the total $\mathrm{N}$ from 20 in MHM to Io in SHM.

In the preparation of the diets a cream containing $200 \mathrm{~g}$ fat $/ \mathrm{kg}$ was made by homogenizing $0.2 \mathrm{~kg}$ fat and $0.08 \mathrm{~kg}$ MHM in $0.72 \mathrm{~kg}$ water. This cream was added to a solution or suspension of the other ingredients as a $1: 9(\mathrm{w} / \mathrm{w})$ mixture to produce $20 \mathrm{~g}$ 
Vol. $3^{6}$

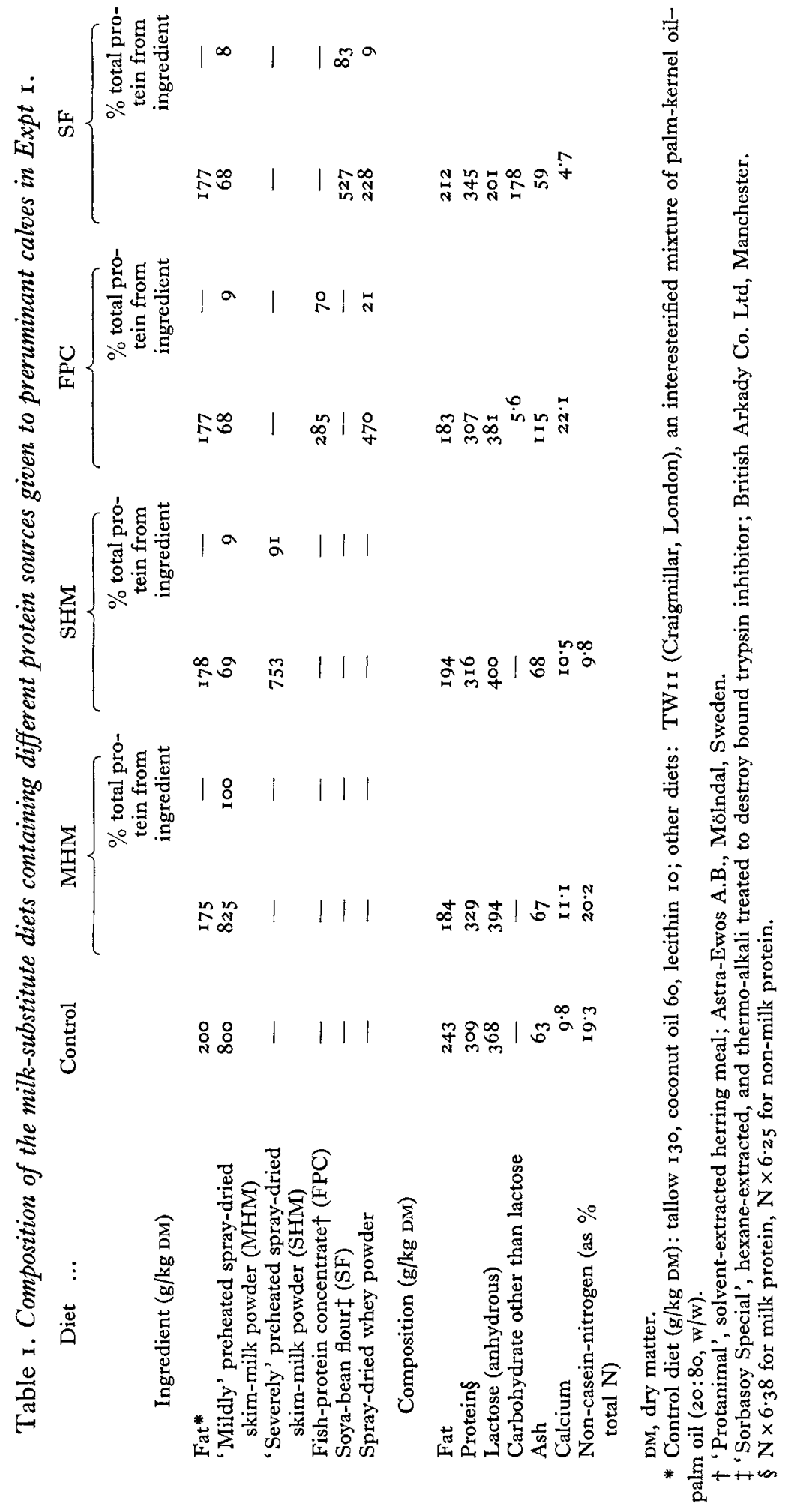


fat $/ \mathrm{kg}$ liquid in each of the four milk-substitute diets. The diets also contained $2 \cdot 4 \mathrm{mg}$ retinol equivalent and $50 \mu \mathrm{g}$ cholecalciferol $/ \mathrm{kg}$ liquid diet (Rovimix; Roche Products Ltd, London WI). In addition, diet SF was supplemented with $0.4 \mathrm{~g}$ DL-methionine/kg liquid.

The fat (TW I I Craigmillar, London), an interesterified mixture of palm-kernel oilpalm oil $(20: 80, \mathrm{w} / \mathrm{w})$, had the following fatty acid composition $(\mathrm{mg} / \mathrm{g}): \mathrm{C}_{8: 0} 8, \mathrm{C}_{10: 0} 8$, $\mathrm{C}_{12: 0} 7_{22}, \mathrm{C}_{14: 0} 39, \mathrm{C}_{16: 0} 434, \mathrm{C}_{16: 1} 3, \mathrm{C}_{17: 0} \mathrm{I}, \mathrm{C}_{18: 0} 55, \mathrm{C}_{18: 1} 295, \mathrm{C}_{18: 2}$ 72, $_{\text {18:3 }}$, $\mathrm{C}_{20: 0} 4, \mathrm{C}_{20: 1} 4, \mathrm{C}_{22: 0}, \mathrm{C}_{22: 1} \mathrm{I}$.

The DM of all diets as fed was $114 \mathrm{~g} / \mathrm{kg}$ and the total daily intake for all diets was $5^{\circ} \mathrm{g} \mathrm{DM} / \mathrm{kg}$ live weight 0.75 .

Sodium chloride 'licks' were available to the calves throughout the experiment.

Experimental diets with high and low DM content. The diets contained a similar milk powder to that used for the control diet in Expt $\mathrm{I}$. The four dietary regimens, ${ }_{15} \mathrm{~L}$, I $5 \mathrm{H}, \mathrm{IOL}$, and $\mathrm{roH}$, were as follows:

DM intake ( $\mathrm{g} / \mathrm{kg}$ live weight ${ }^{0.75}$ per $\left.\mathrm{d}\right)$

$\mathrm{DM}$ concentration $(\mathrm{g} / \mathrm{kg}$ liquid diet)

Liquid intake $\left(\mathrm{kg} / \mathrm{kg}\right.$ live weight ${ }^{0.75}$ per $\left.\mathrm{d}\right)$

$\begin{array}{cccc}{ }_{15} \mathrm{~L} & { }_{15} \mathrm{H} & 10 \mathrm{~L} & 10 \mathrm{H} \\ 32 \cdot 5 & 49 \cdot 0 & 32 \cdot 5 & 49 \cdot 0 \\ 149 & 149 & 100 & 100 \\ 0.22 & 0.33 & 0.33 & 0.49\end{array}$

\section{Surgery}

Vagally innervated fundic pouches (Hill \& Gregory, $195 \mathrm{r}$ ) were prepared as soon as the calves were consuming satisfactory amounts of the control diet. T-shaped cannulas, made of polyacetal (Kematal; ICI Ltd, Welwyn Garden City, Herts), were inserted in the pouch and also in the remaining fundus for sampling of abomasal digesta. The cannulas were threaded and were $12 \mathrm{~mm}$ i.d., $16 \mathrm{~mm}$ o.d., and $55 \mathrm{~mm}$ long with gutters $66 \mathrm{~mm} \times \mathrm{I} 6 \mathrm{~mm}$. Threaded retaining discs maintained them in position.

\section{Post-operative care}

The calves were given $6 \times 10^{5} \mathrm{U}$ penicillin (Dista Products Ltd, Liverpool) intramuscularly immediately on completion of surgery. For the first few days after the operation, the position of the retaining disc was checked frequently and adjusted to prevent undue tension on the abdominal wall. The pouches were washed out with I00 $\mathrm{ml}$ warmed sterile saline solution $(9 \mathrm{~g} \mathrm{NaCl} / 1)$ three times daily for $3 \mathrm{~d}$ and then at least once daily for the next II $\mathrm{d}$.

After about I4 d, silastic 'mushroom' catheters (Dow Corning Corp., Medical Products Division, Midland, Michigan 48640, USA), size FR 28 or 32 depending on the depth of the pouches, were inserted to aid drainage of the gastric juice. A Perspex elbow carrying a short length of plastic tubing was attached to the cannulas when collections were not being made, to drain the gastric juice away from the flank of the animal.

\section{Feeding procedure}

The milk-substitute diets were bucket-fed in equal quantities twice daily at 09.00 and 17.00 hours. Most of the feed, which was given at a temperature of $37^{\circ}$, was 
consumed in a few minutes. Usually twelve meals were given in each experimental period and eight in each control period, the first meal being at 17.00 hours. Meals $1-5$ were used to accustom the calf to the diet.

\section{Collection of gastric juice}

The first studies of pouch secretion were unsuccessful because the collection apparatus was too heavy and caused irritation of the pouch mucosa by movement of the cannula. Mean values for samples collected over a number of $8 \mathrm{~h}$ periods were $\mathrm{pH} 7 \cdot 4$, and ion concentrations (mmol/l): sodium $144 \cdot 2$, potassium $8 \cdot 05$, chloride 114.5 .

After the development of a light-weight apparatus, successful collections were made. For these, the pouch was probed carefully with a rod of $5 \mathrm{~mm}$ diameter to ensure that it was fully drained and then an L-shaped connecting tube, made of Perspex, was threaded onto the pouch cannulas. The L-piece had a fine air-hole on its upper surface, and a threaded cap on its lower end for the attachment of a $60 \mathrm{ml}$ polyethylene bottle. The total weight of empty bottle plus L-piece was ig g. The collection bottle was replaced every ${ }_{5} \mathrm{~min}$ and the juice obtained was bulked in a glass bottle held in an ice pack. At the end of each hour of collection, the volume, $\mathrm{pH}$ and titratable acidity of the bulked sample were measured. A sample was also stored at $-20^{\circ}$ until it could be assayed for proteolytic activity. Mean values for four $8 \mathrm{~h}$ collection periods, obtained with the lighter equipment, were $\mathrm{pH} \mathrm{x} \cdot 6$, and $(\mathrm{mmol} / \mathrm{l})$ $\mathrm{Na}^{+} 35^{\circ} \mathrm{O}, \mathrm{K}^{+}$I I $8, \mathrm{Cl}^{-}$I $17 \cdot 4$.

In Expt I, gastric juice was collected quantitatively from the pouches each hour between 09.00 and 17.00 hours on two consecutive days after meals 10 and 12 of each experimental period, and after meals 6 and 8 of each control period. If any portion of these meals was refused the day of collection was delayed.

In Expt 2, insufficient values were obtained from the pouches to assess differences between diets.

\section{Sampling of abomasal digesta}

Abomasal digesta samples were obtained immediately before feeding meals 6 and 8 at 09.00 hours and then at hourly intervals until 17.00 hours when the calf was given its evening meal. Thus, nine samples were obtained on each of the two consecutive days.

\section{Chemical analysis}

$p H$. This was measured immediately after sampling, using a glass electrode with a Pye No. 72 meter (Pye-Unicam Ltd, Cambridge). The total free hydrogen ion secretion was calculated from the expression $\mathrm{pH}=-\log _{10}\left[\mathrm{H}^{+}\right]$, where $\left[\mathrm{H}^{+}\right]$is the $\mathrm{H}^{+}$ concentration, and from the volume of secretion.

Total titratable acidity. Gastric juice was titrated with $O \cdot I$ M-sodium hydroxide using phenolphthalein as an indicator. Abomasal digesta, after $\mathrm{pH}$ determination, were centrifuged for ro min at $2365 \mathrm{~g}$. The cap of solid digesta and liquid fat was removed by suction and $5 \mathrm{ml}$ of the supernatant fluid fraction were titrated with $0.1 \mathrm{M}-\mathrm{NaOH}$ using phenolphthalein as an indicator. 
Proteolytic activity. Proteolytic activity of the gastric juice was determined by the release of tyrosine in $15 \mathrm{~min}$ from a solution $(20 \mathrm{~g} / 1)$ of bovine haemoglobin (powder type II; Sigma Chemical Co., St Louis, Missouri, USA) in hydrochloric acid at pH $2 \cdot 1$ (pepsin activity) and 3.5 (rennin activity) (Anson, I938). Gastric juice was diluted $\mathrm{r}: 6(\mathrm{v} / \mathrm{v})$ with $\mathrm{HCl}$ at $\mathrm{pH} 2.1$ or 3.5 , and $\mathrm{I} \mathrm{ml}$ was added to $5 \mathrm{ml}$ haemoglobin solution in $\mathrm{HCl}$ at $\mathrm{pH} 2 . \mathrm{I}$ or 3.5 . All solutions were equilibrated to $37^{\circ}$ before the assay. After incubation at $37^{\circ}$ for $\mathrm{I} 5 \mathrm{~min}$, the contents of each assay tube were poured into $6 \mathrm{ml} 0.6 \mathrm{I} \mathrm{M}$-trichloroacetic acid (TCA) and mixed. After protein precipitation, the samples were filtered (Whatman No. I paper) and the extinction at $278 \mathrm{~nm}$ of the supernatant fraction was measured using a Unicam SP 500 spectrophotometer (PyeUnicam Ltd).

A set of blank tubes was set up for each determination; I $\mathrm{ml}$ diluted gastric juice was pipetted directly into $6 \mathrm{ml}$ TCA. After incubation for $15 \mathrm{~min}, 5 \mathrm{ml}$ substrate solution were added and mixed. The extinction value of the 'assay' tubes was corrected for that of the 'blank' tubes.

One unit of proteolytic activity was defined as $\mathrm{r} \mu \mathrm{mol}$ tyrosine released $/ \mathrm{min}$.

$\mathrm{pH} v$. proteolytic activity curves were also obtained on a number of occasions. Substrate at $\mathrm{pH}$ values of $\mathrm{I}^{\circ} \mathrm{O}^{-5} \cdot 0$, at intervals of 0.5 units of activity, was used. Since the addition of alkali caused substrate precipitation, it was found to be more practical to make up a solution at $\mathrm{pH} 5^{\circ} \mathrm{O}$ and then adjust the $\mathrm{pH}$ with $6 \mathrm{M}-\mathrm{HCl}$. An extra tube was also set up at each $\mathrm{pH}$, so that the true $\mathrm{pH}$ at which the incubation took place could be determined. This was necessary because dilutions of the test samples were made at $\mathrm{pH}_{2} \cdot \mathrm{I}$ and $\mathrm{pH}_{3.5}$ only.

Cl. Whitehorn's (1921) method was used.

$\mathrm{Na}$ and $\mathrm{K}$. $\mathrm{Na}$ and $\mathrm{K}$ were determined using a flame spectrophotometer (Unicam SP 900; Pye-Unicam Ltd). Na was measured at $588 \mathrm{~nm}$ and $\mathrm{K}$ at $757 \mathrm{~nm}$.

\section{Statistical analysis}

In Expt I, there are two missing treatments (diets SHM and SF) for calf 8 because of the deterioration of the pouch. The values for all pouch characteristics measured for calf 8 given these two treatments were calculated by the technique of Yates (1933). For the pouch secretion results, covariance analysis of the value for the experimental diets $v$. the mean values for the control diet, obtained at the collection just preceding and succeeding the experimental period, was made. In the analysis of variance, the variation due to periods was in no instance significant and if the (error + periods) mean square gave a lower value, this was used instead of the error mean square.

In Expts $\mathrm{I}$ and 2 the significance of the difference between mean values for $\mathrm{pH}$ and titratable acidity of abomasal digesta obtained before and after giving the different diets was tested by Student's $t$ test.

For the comparison of buffering capacity of abomasal digesta fluid, linear regressions of $\mathrm{pH} v$. titratable acidity were calculated for each calf on each diet and differences in the position and slope of the regression were determined within each calf. 


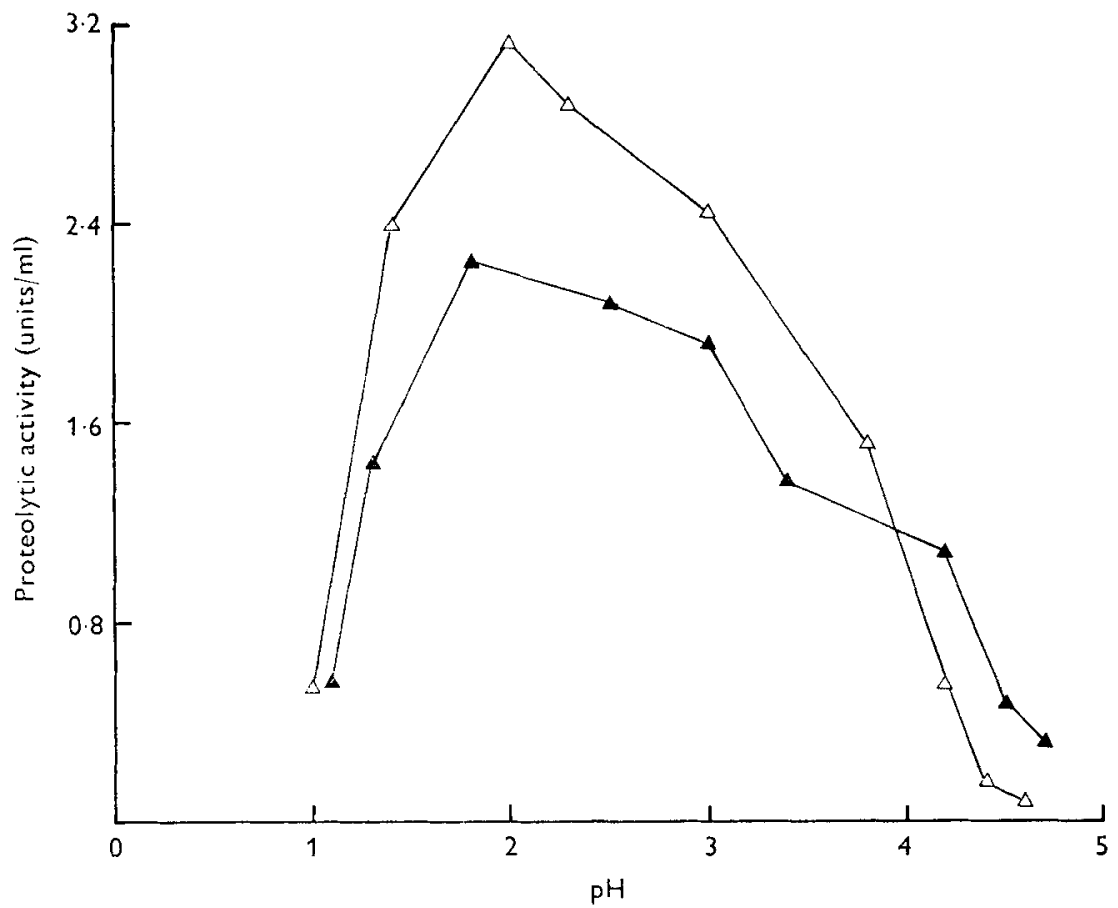

Fig. r. Expt 2. Proteolytic activity (units $/ \mathrm{ml}$ ), determined at different $\mathrm{pH}$ values, in fundic pouch secretion $(\Delta)$ and abomasal digesta fluid $(\Delta)$ obtained concurrently from calf 4 when given a diet containing 'mildly' preheated, spray-dried skim-milk powder, with added tallow and coconut oil, at $\mathrm{I} 49 \mathrm{~g}$ dry matter/kg liquid diet, fed at the high level (dietary regimen $\mathrm{I}_{5} \mathrm{H}$; for details, see p. 320). Mean values for determinations on two consecutive days. One unit of proteolytic activity was defined as I $\mu \mathrm{mol}$ tyrosine released $/ \mathrm{min}$.

\section{RESULTS}

\section{Calf health and growth}

All calves grew satisfactorily whilst on experiment. Food refusals usually occurred when diarrhoea, constipation or increased body temperature were apparent and also when the animals were changed to diet SF. When this diet was given, the output of faeces was markedly increased.

\section{Proteolytic activity of abomasal digesta fluid and fundic pouch secretion determined at different $p H$ values}

This was found to be similar for abomasal digesta fluid and for pouch secretion collected concurrently. An example of the determination for calf 4 is given in Fig. I. The maximum activity of both curves was at approximately the same $\mathrm{pH}$. The ratio, activity at $\mathrm{pH}_{3} \cdot 5$ :activity at $\mathrm{pH} 2 \cdot \mathrm{I}$ was $\mathrm{I}: \mathrm{x} \cdot 62$ for the pouch secretion and $\mathrm{I}: \mathrm{I} \cdot 6 \mathrm{I}$ for abomasal fluid.

\section{Effect of time after feeding}

$p H$, volume and titratable acid output of fundic pouch secretion. The trend usually found in $\mathrm{pH}$, volume and total titratable acid output of fundic pouch secretion relative to time after feeding is shown in Fig. 2. The volume of secretion usually reached 

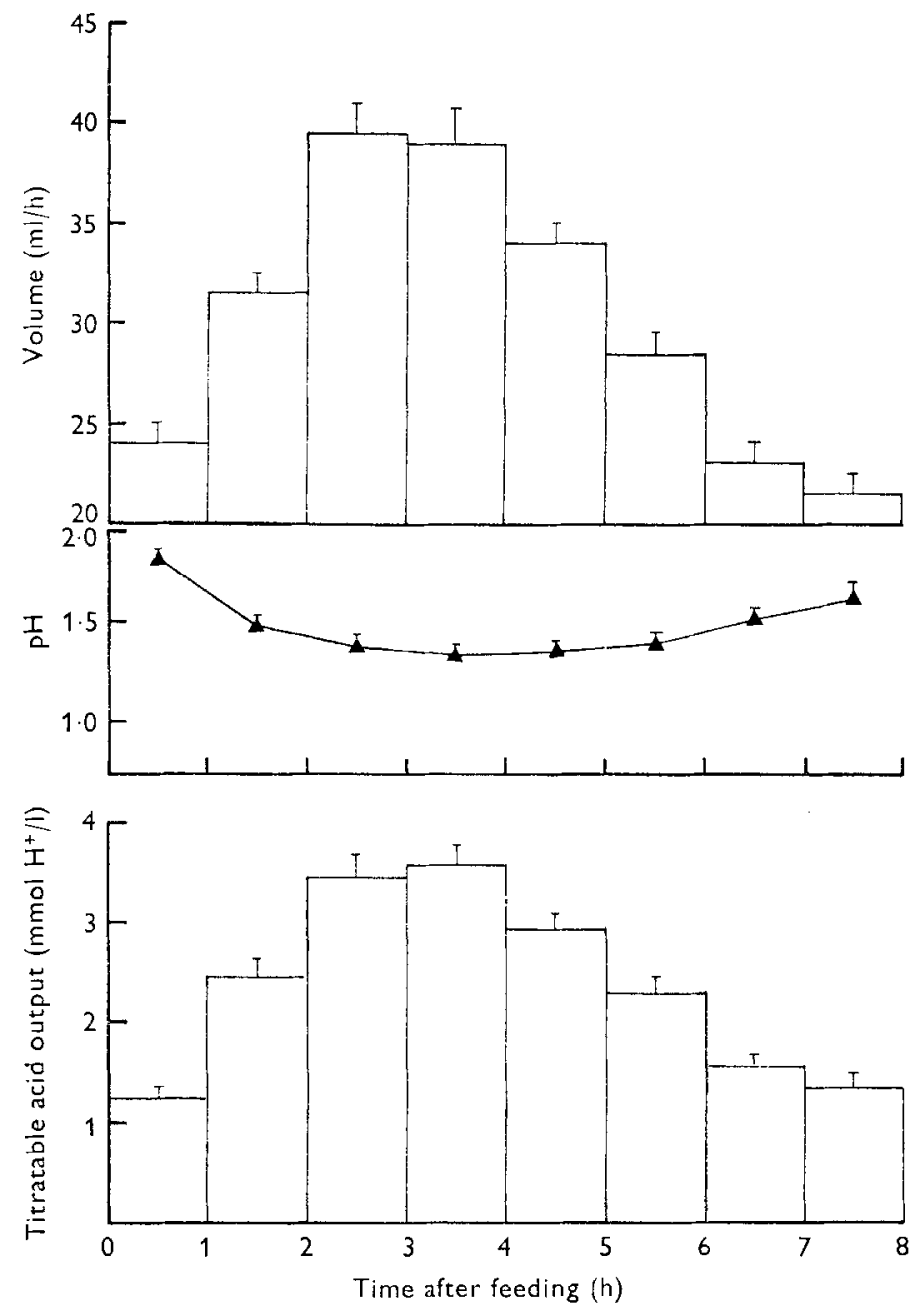

Fig. 2. Expt I. Effect of time after feeding (h) on volume $(\mathrm{ml} / \mathrm{h})$ and $\mathrm{pH}$ of fundic pouch secretion, and total titratable acid output ( $\mathrm{mmol}$ hydrogen ions/h) of preruminant calves with fundic pouches; mean values with their standard errors, represented by vertical bars, for calves 4, 6, 7 and 8 given the control diet ("mildly' preheated, spray-dried skim-milk powder with added tallow and coconut oil; for details, see Table $\mathbf{I}$ ).

a maximum during the 3 rd and 4 th hour after feeding and decreased in the last $4 \mathrm{~h}$ before the evening meal. The $\mathrm{pH}$ of the secretion was inversely related to volume and the trend for hourly output of titratable acid closely approximated to the pattern for volume of secretion.

Proteolytic activity of pouch secretion. Fig. 3 shows the change in the amount (units/ $\mathrm{ml}$ ) and total output (units/h) of proteolytic activity in fundic pouch secretion with time after giving the control diet. The activity at $\mathrm{pH} 2 . \mathrm{I}$ exceeded that at $\mathrm{pH} 3.5$ at all times in both amount and total output. Total enzyme ouput, in contrast to total titratable acid output (Fig. 2) was inversely related to the volume of secretion, but directly related to the amount of activity. 

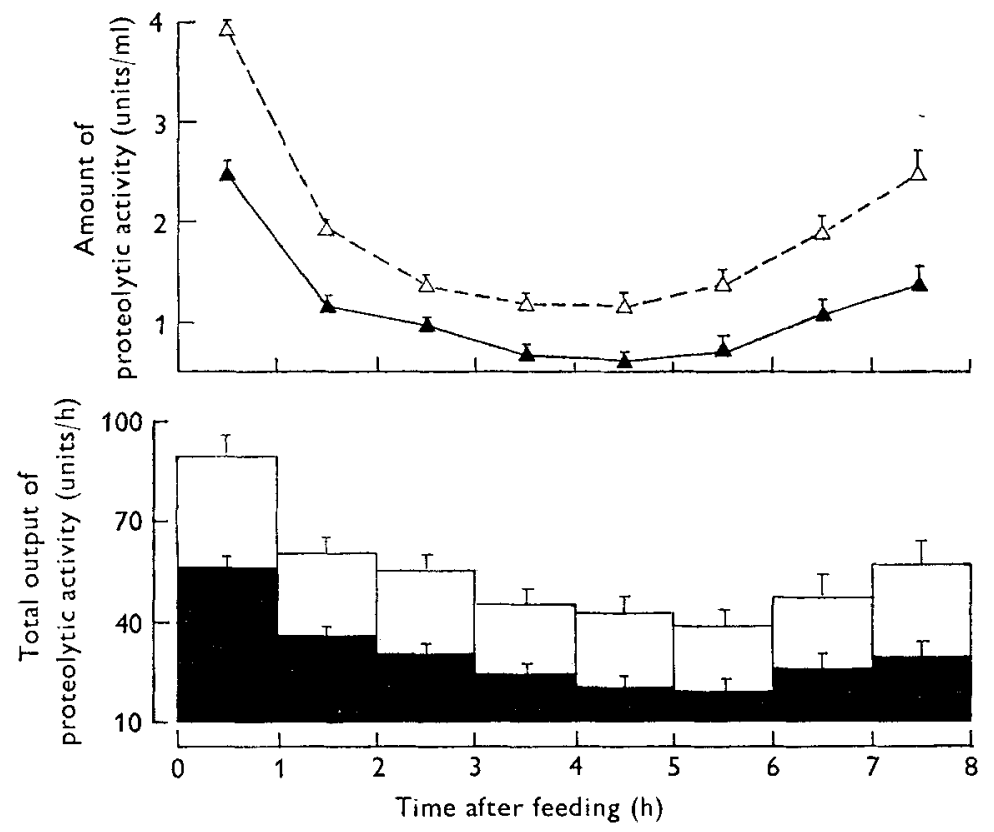

Fig. 3. Expt r. Effect of time after feeding (h) on the amount (units/ml) and total output of proteolytic activity (units/h), assayed at $\mathrm{pH} 2 \cdot \mathrm{I}$ and 3.5 , in fundic pouch secretion of preruminant calves with fundic pouches; mean values with their standard errors, represented by vertical bars, for calves $4,6,7$ and 8 given control diet ('mildly' preheated, spray-dried skim-milk powder, with added tallow and coconut oil; for details, see Table r). Activity: $(\triangle---\triangle)$, pH 2. I ( $\mathbf{\Delta}-\mathbf{\Delta}), \mathrm{pH}_{3.5}$; total output of activity: $(\square), \mathrm{pH}_{2} \cdot \mathrm{I}(\mathbf{\square}), \mathrm{pH}_{3} \cdot 5$. One unit of proteolytic activity was defined as I $\mu \mathrm{mol}$ tyrosine released/min.

\section{Effect of age on pouch secretion}

Volume of secretion. Regression analysis of the volume of pouch secretion for days when the control diet was fed indicated that there was a significant decrease $(P<0.01)$ with age only in calf 6 . However, there was no difference in slopes of the regressions between the calves, although there were significant differences in position of the regressions. The combined regression coefficient was $-0.035 \pm 0.0155 \mathrm{ml} / \mathrm{kg}$ live weight $t^{0.75}$ per $8 \mathrm{~h}$ per $\mathrm{d}$ of age $(P<0.05)$.

Titratable acidity. Titratable acidity of the pouch secretion after the control diet had been given increased significantly with age only in calf $8\left(0.014 \pm 0.0039 \mathrm{mmol} \mathrm{H}^{+}\right.$/ $\mathrm{kg}$ live weight ${ }^{0.75}$ per $8 \mathrm{~h}$ per $\mathrm{d}$ of age $\left.(P<0.05)\right)$. There was a highly significant difference in positions and slopes of the regressions between calves, the other calves had decreased values ranging from -0.0002 to $-0.003 \mathrm{mmol} \mathrm{H}^{+} / \mathrm{kg}$ live weight ${ }^{0.75}$ per $8 \mathrm{~h}$ per $\mathrm{d}$ of age.

Proteolytic activity. Regression analyses were made for proteolytic activity of the pouch secretion obtained when the control diet was given $v$. age.

Calf 6 was the only animal which had a significant decrease in activity with age at both $\mathrm{pH} 2.1$ and $3.5(P<0.01)$, the decrease being $-0.163 \pm 0.044$ and -0.260 \pm 0.054 units $/ \mathrm{kg}$ live weight ${ }^{0.75}$ per $8 \mathrm{~h}$ per $\mathrm{d}$ of age respectively. Since activity decreased faster at $\mathrm{pH}_{3.5}$ than at $\mathrm{pH} 2 \cdot \mathrm{I}$, the regression coefficient for the ratio, 

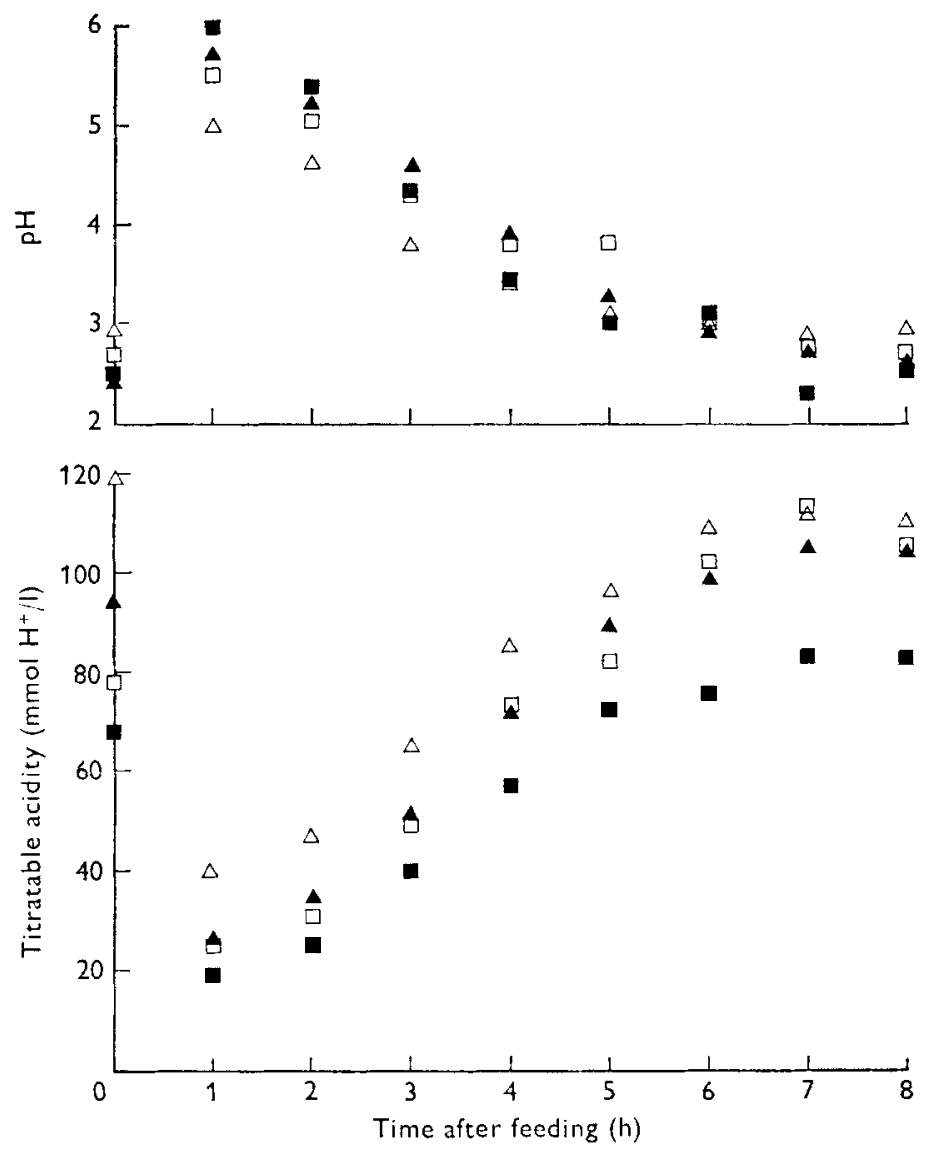

Fig. 4. Expt I. Effect of dietary protein source on $\mathrm{pH}$ and titratable acidity (mmol hydrogen ions/l) of abomasal digesta fluid from preruminant calves with fundic pouches. $(\Delta)$, Diet with 'mildly' preheated, spray-dried skim-milk powder; $(\boldsymbol{\Delta})$, diet with 'severely' preheated spraydried skim-milk powder; $(\square)$, diet with fish-protein concentrate; $(\square)$, diet with soya-bean flour; for details of diets, see Table I. Significance of differences tested by Student's $t$ test: $\mathrm{pH}: \Delta<\Delta$ at $\mathrm{I}, 2$ and $3 \mathrm{~h} ; \Delta<\square$ at $2 \mathrm{~h} ; \Delta<\mathbf{a}$ at $\mathrm{I}$ and $2 \mathrm{~h}$; titratable acid: $\Delta<\boldsymbol{\Delta}$ at I, 2 and $3 \mathrm{~h} ; \triangle<\square$ at $0, \mathrm{I}, 2$ and $3 \mathrm{~h} ; \Delta<\square$ at $0, \mathrm{r}, 2,3,4$ and $5 \mathrm{~h}$ (all statistically significant $(P<0.05))$.

activity at $\mathrm{pH} 2 \cdot 1$ :activity at $\mathrm{pH} 3.5 \%$. age was positive and significant $(P<0.05)$. The values for activity at $\mathrm{pH} 2 \cdot 1$ suggest that the pouch of calf 6 was deteriorating with age.

For activity at both $\mathrm{pH} 2 \cdot \mathrm{I}$ and $\mathrm{pH}_{3} \cdot 5$, there were differences between calves in the position but not in the slope of the regression; the combined regression coefficients were therefore used. There was a significant decrease in activity at $\mathrm{pH} 3.5$ with age $\left(-0.115 \pm 0.053\right.$ units $/ \mathrm{kg}$ live weight ${ }^{0.75}$ per $8 \mathrm{~h}$ per $\mathrm{d}$ of age; $\left.P<0.05\right)$, but not at $\mathrm{pH} 2 \cdot \mathrm{I}$. The regression for the ratio, activity at $\mathrm{pH} 2 \cdot \mathrm{I}$ : activity at $\mathrm{pH}_{3.5} \mathrm{v}$. age was positive and also significant $(P<0.05)$. 
Expt 1. Effect of dietary protein source

Buffering capacity and ability to clot of the experimental diets in vitro

Buffer curves determined for the four diets indicated that there was no difference between diets MHM and SHM, but both these diets had greater buffering capacity than diet FPC between $\mathrm{pH}_{4.2}$ and 6.5 and greater capacity than diet $\mathrm{SF}$ between $\mathrm{pH}$ $3 \cdot 0$ and $6 \cdot 0$. However, diet FPC had greater buffering capacity than diets MHM, SHM and $\mathrm{SF}$ between $\mathrm{pH} 2 \cdot 0$ and $4 \cdot 2$.

The ability of the diets to clot differed markedly. Diet MHM produced a tough clot, diet SHM a crumbly clot and diets FPC and SF showed no coagulation with rennin in vitro.

\section{Acidity of abomasal digesta}

Digesta $p H$. The pH of the digesta obtained before and after feeding is shown in Fig. 4. The significant differences clearly indicate that the $\mathrm{pH}$ was lower $\mathrm{I}-2 \mathrm{~h}$ after giving diet MHM than after giving the other three diets.

Titratable acidity of digesta fluid. Fig. 4 shows that up to $3 \mathrm{~h}$ after feeding the values for diet MHM were higher than those for the other three diets. The values for diet SF were significantly lower than those for diet MHM for the first $5 \mathrm{~h}$ after feeding.

Buffering capacity of digesta fluid. The linear regressions of digesta $\mathrm{pH} v$. total titratable acidity of the digesta fluid are given in Table 2. Samples obtained before feeding were excluded from the analysis because of their high variability. Analyses of variance indicated very highly significant differences between animals, as well as differences between diets within animals; correlation coefficients within animals and within diets were significant (at least $P<0.01$ ). The results indicated a marked difference in the regression coefficients for diet SF compared with those for the other three diets when comparisons within calves were made. Digesta fluid from diet $\mathrm{SF}$ had a lower $\mathrm{pH}$ for a given titratable acidity in all four calves over most of the range in $\mathrm{pH}$ used in the determinations. Thus, the digesta fluid from diet SF was less well buffered than that from the other diets.

\section{Pouch secretion}

The results are given in Table 3 in which the values are expressed on a per $\mathrm{kg}$ live weight $\mathbf{0 . 7 5}$ per $8 \mathrm{~h}$ basis to account for the growth of the pouch with increase in live weight of the calf.

The variability in secretion on consecutive days was very great. The volume of secretion was the least variable and the proteolytic activity at $\mathrm{pH}_{3.5}$ was the most variable.

Regressions of the experimental diet values $v$. those for the control diet were not significant; thus inclusion of the control diet in the experiment was of no value in obtaining a more precise measure of the differences between the experimental diets.

Volume. The greatest volume of pouch secretion was produced with diet FPC and the lowest with diet SF. The results also indicated that diet SHM produced a volume of secretion intermediate between those of diets MHM and SF. 


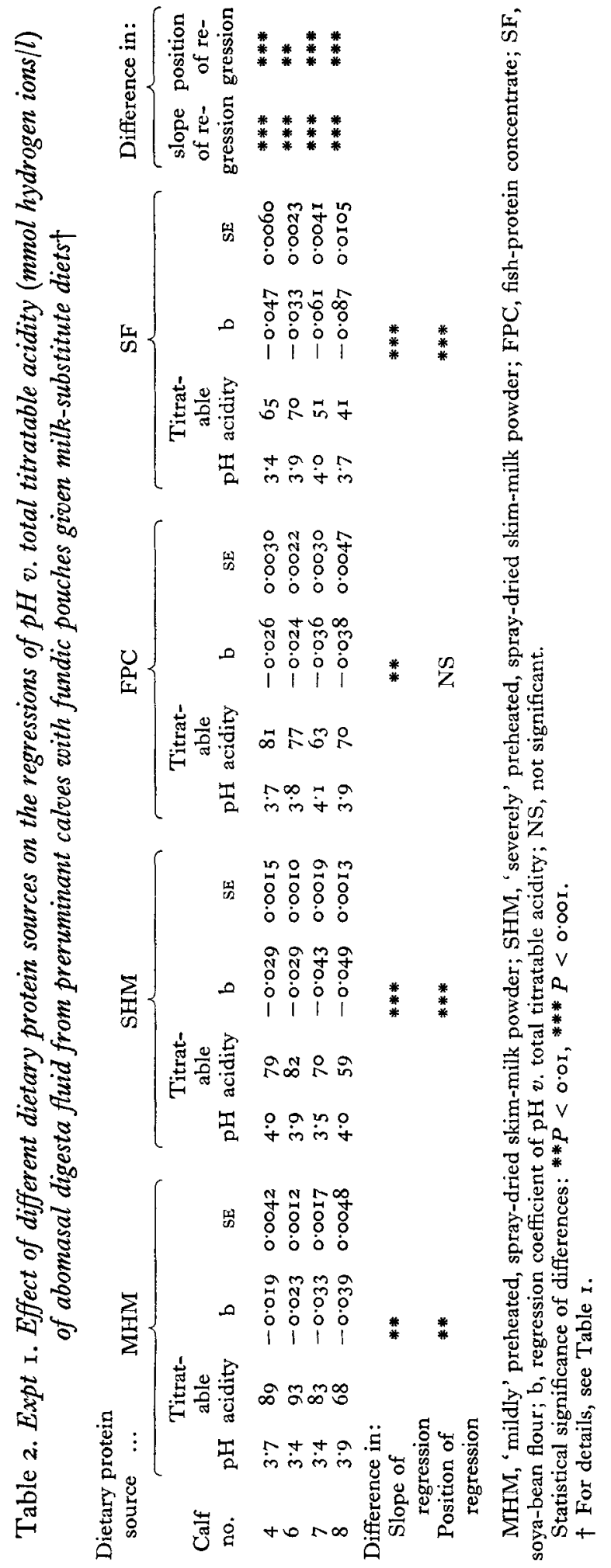


Vol. $3^{6}$

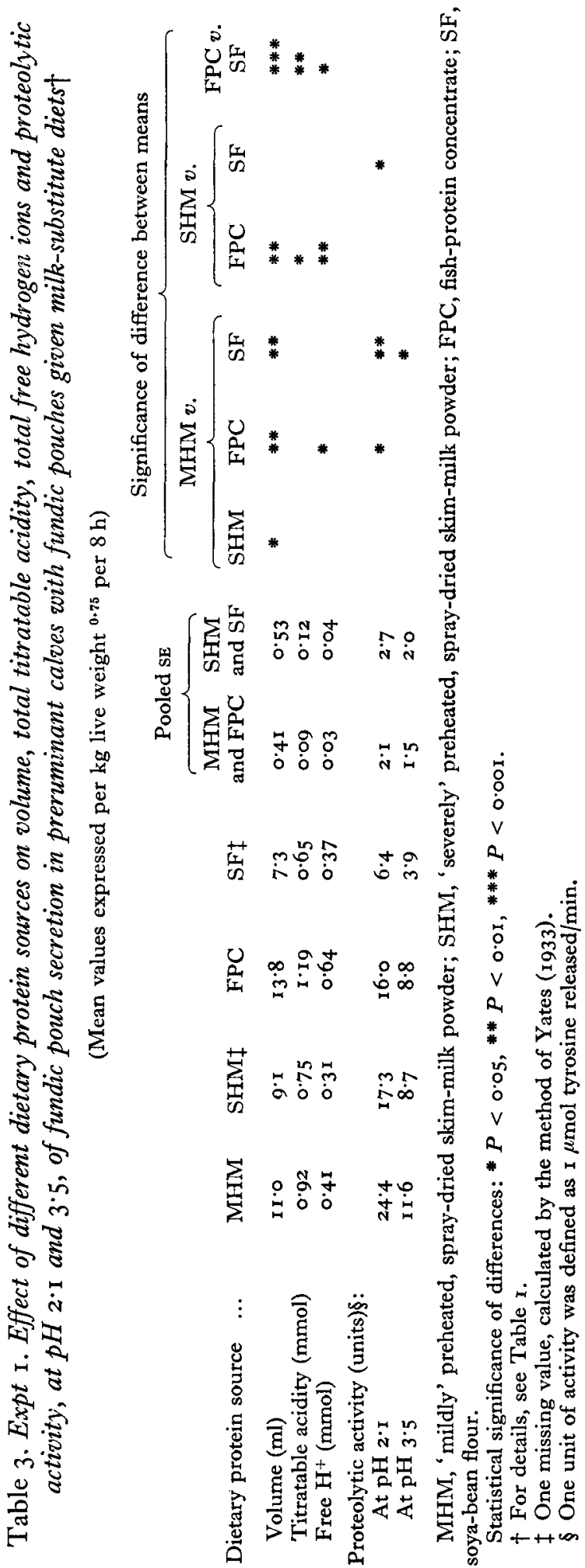




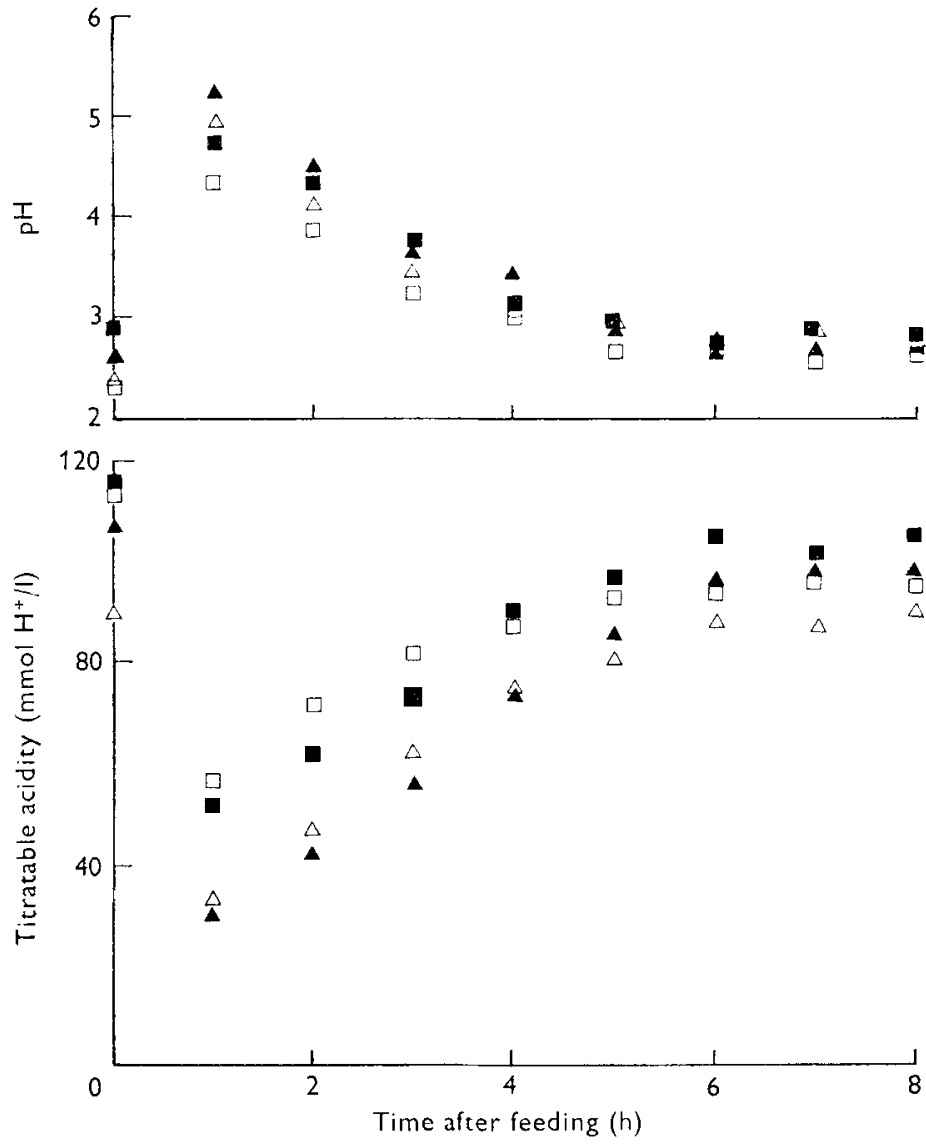

Fig. 5. Expt 2. Effect of dry matter (DM) concentration and $\mathrm{DM}$ intake on $\mathrm{pH}$ and titratable acidity (mmol hydrogen ions/1) of abomasal digesta fluid from preruminant calves with fundic pouches. Diet with 'mildly' preheated, spray-dried skim-milk powder, and added tallow and coconut oil: $100 \mathrm{~g} \mathrm{DM} / \mathrm{kg}$ liquid diet, fed at the low $(\triangle)$ and high $(\Delta)$ level; $149 \mathrm{~g} \mathrm{DM} / \mathrm{kg}$ liquid diet, fed at the low $(\square)$ and high $(\square)$ level; for details of diet and of dietary regimens, see Table 1 and p. 320 respectively. Significance of differences tested by Student's $t$ test: $\mathrm{pH}$ :

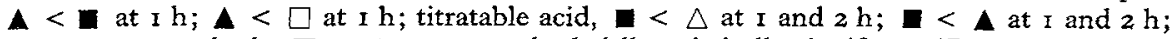
$\square<\Delta$ at $\mathrm{I}$ and $2 \mathrm{~h} ; \square<\Delta$ at $\mathrm{I}, 2$ and $3 \mathrm{~h}$ (all statistically significant $(P<0.05)$ ).

Titratable acidity. Diet FPC produced more total titratable acidity than either diet SHM or diet SF, but there was no significant difference between diets MHM, SHM and SF. However, the trend in these results suggested strongly that secretion was in the order: diet FPC > diet MHM > diet SHM > diet SF.

Free $\mathrm{H}^{+}$. The values for free $\mathrm{H}^{+}$: total titratable acidity in the secretions with the

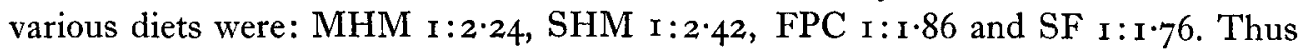
diets FPC and SF produced more free acid:total acid than the two milk-protein diets (MHM and SHM).

Differences in free $\mathrm{H}^{+}$between diets were unlike those of total titratable acidity, in that diet FPC produced significantly more free $\mathrm{H}^{+}$than diet MHM, as well as producing more than diets SHM and SF.

Proteolytic activity. There was a clear indication that the proteolytic activity at 
Vol. 36

盗

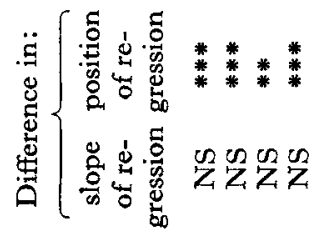

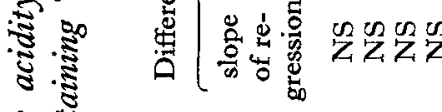

ริ ซิ

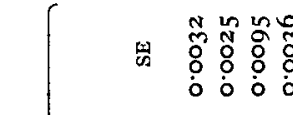

을

ฐ

के

촐

5

产

密

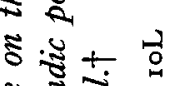

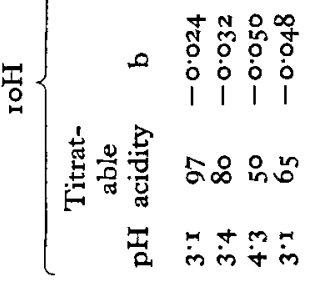

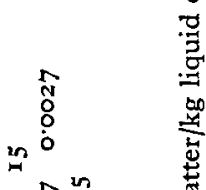

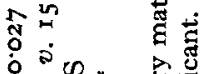

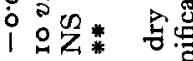

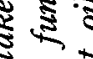

है

돌 응

ํํำ

ㄴำ

密

突

홀

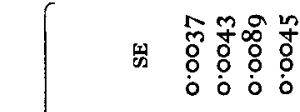

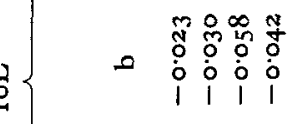

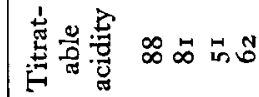

$: \frac{\pi}{2}$

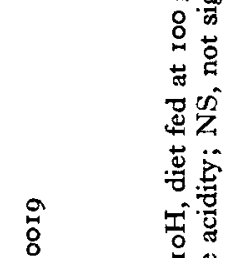

웅

i

离

के

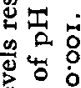

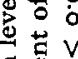

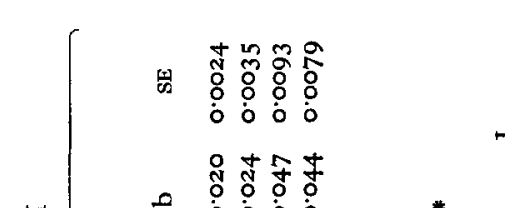

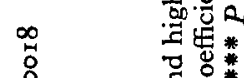

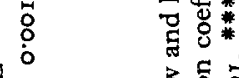

A.

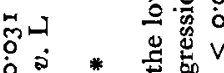

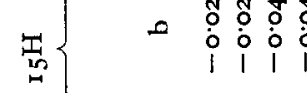

江 ** 苟造

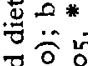

政

$=\dot{i} v$

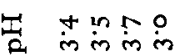

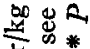

원

ชิ $\overline{5}$

บิ $\frac{5}{2}$

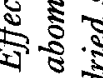

त 8 i

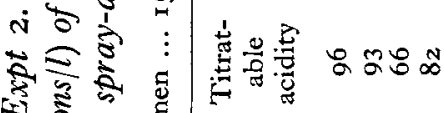

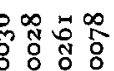

N

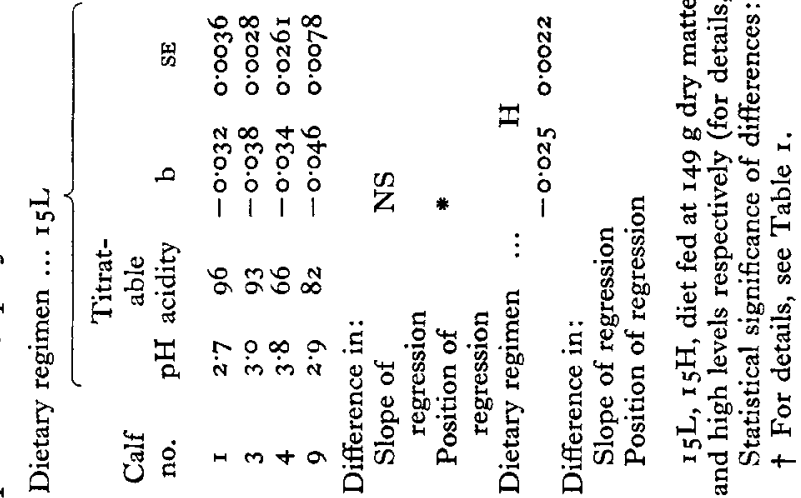


pH 2. $\mathrm{I}$ was in the order diet MHM > diet FPC > diet SF, with diet SHM approximating to that of diet FPC. The ratio, activity at $\mathrm{pH} 2 \cdot \mathrm{I}$ : activity at $\mathrm{pH} 3.5$ did not differ between diets; the mean values with their standard errors were: diet MHM 2.2 $\pm 0 \cdot 2: 1$, diet SHM 2.1 $\pm 0.3: 1$, diet FPC $1 \cdot 8 \pm 0 \cdot 2: 1$, diet SF $2 \cdot 2 \pm 0.3: 1$.

The results for proteolytic activity at $\mathrm{pH} 3.5$ indicated no significant effect due to diet.

\section{Expt 2. Effect of dietary DM concentration and $\mathrm{DM}$ intake}

$p H$ of abomasal digesta. During the first $5 \mathrm{~h}$ after feeding, digesta $\mathrm{pH}$ was lowest for dietary regimen ${ }_{5} \mathrm{~L}$ (Fig. 5 ), but the only significant difference was at $\mathrm{I} h$ after feeding, when digesta $\mathrm{pH}$ for dietary regimen $10 \mathrm{H}$ was higher than for ${ }_{15} \mathrm{H}$ and ${ }_{15} \mathrm{~L}$.

Total titratable acidity of the digesta fluid. This was significantly higher for dietary regimens ${ }_{5} \mathrm{H}$ and ${ }_{5} \mathrm{~L}$ than for $10 \mathrm{H}$ and $10 \mathrm{~L}$ during the first $2 \mathrm{~h}$ after feeding, but the trend was still apparent $5 \mathrm{~h}$ after feeding (Fig. 5).

Buffering capacity of digesta fluid. This was determined as for Expt $\mathrm{r}$. The results for the regression of $\mathrm{pH} v$. titratable acidity are given in Table 4 . There was no significant difference within individual calves in the buffering capacity of the diet with the four dietary regimens, although within each calf there were highly significant differences in the positions of the regressions.

Within dietary regimens, there were significant differences in the slope $\left({ }_{5} \mathrm{H}, 10 \mathrm{~L}\right.$, $\mathrm{roH})$ and position $\left({ }_{1} \mathrm{~L},{ }_{15} \mathrm{H}, 10 \mathrm{H}\right)$ of regression between calves. Over all there was a significantly higher $(P<0.05)$ buffering capacity for the diet at the $\mathrm{H}$ level compared with that at the $L$ level, but no effect of DM concentration, although the interaction between DM intake and concentration was also significant.

\section{DISCUSSION}

The effective life of the pouches and fundic fistulas was limited due to the gradual rejection of the cannulas by the natural growth of tissues. The use of the silastic 'mushroom' catheters to maintain drainage from the pouches was a great advantage, and a collection apparatus, which was very light in weight and which minimized the movement of the cannula was also essential.

When digesta were obtained from the fundic cannulas, a representative sample was not always achieved. This was particularly true for the first $\mathbf{3}$-hourly samples after feeding diet MHM because of very firm clot formation (Tagari \& Roy, 1969). Consequently it was decided to centrifuge the digesta and titrate the supernatant fraction to obtain comparative values for titratable acidity for the different diets. It seems reasonable that substances in the supernatant fraction would have dominated the buffering capacity of the digesta against acid in vivo. The highly significant linear correlations between the $\mathrm{pH}$ of digesta fluids and total titratable acidities suggested that the fluids were acting homogeneously as buffers within each calf.

The results from Expt 2 suggest that $\mathrm{pH}$ and titratable acidity are affected by the volume of liquid intake, since dietary regimen $\mathrm{roH}$ resulted in the highest $\mathrm{pH}$ and the lowest titratable acidity in the digesta $\mathrm{O}-4 \mathrm{~h}$ after feeding. This does not necessarily mean that acid secretion was less for this regimen than for ${ }_{15} \mathrm{H}$, since the secretion 
was mixed with a greater volume of diet. It may also be inferred from a comparison of the results for dietary regimens $10 \mathrm{~L}$ and ${ }_{15} \mathrm{H}$, for which volumes of intake were the same, that a higher concentration of DM, and hence higher DM intake, may increase acid secretion.

In Expt I, DM intake and volume on a per kg live weight ${ }^{0.75}$ basis were the same for all diets and thus distension of the abomasal wall after a feed, other than that induced by different clotting characteristics, should have been similar; this should have reduced the variation in gastric emptying rate (Ash, I964; Mylrea, 1966) and secretion (Ash, I96I) that may have arisen from this cause.

The experimental diets also had the same fat content. Fat in the duodenum of the adult goat is known to influence abomasal emptying rate (Singleton, I95I). However, in the milk-fed calf Ternouth et al. (1974) were unable to show any effect on gastric emptying of the fluid phase by the addition of $20 \mathrm{~g}$ margarine fat $/ \mathrm{kg}$ to a skim-milk diet, although both in that experiment and in further work (Ternouth et al. 1975) there was an indication that protein- $\mathrm{N}$ passed out of the abomasum more quickly when the diet contained additional fat. Espe \& Cannon (1935) produced some evidence, which has been criticized by Hill (I968), that milk containing $60 \mathrm{~g}$ fat $/ \mathrm{kg}$ left the abomasum faster than skim milk, which suggested that inclusion of fat resulted in a less firm clot.

The amounts of FPC and SF included in the diets were the maximum that would allow the protein and carbohydrate contents to be comparable to those of the diets containing milk protein. Consequently, the percentage of total dietary protein derived from the FPC and SF was different. It was considered that to maximize the protein from non-milk sources was more important than an identical contribution.

Because the total carbohydrate content of the diets was balanced, diet SF contained less lactose $(200 \mathrm{~g} / \mathrm{kg} \mathrm{DM})$ than the other three diets ( $400 \mathrm{~g} / \mathrm{kg} \mathrm{DM})$. Although Bell \& Razig (1973) found that lactose inhibits abomasal emptying and acid production, the effect of the carbohydrate in SF on these two factors is not known. Lactose apparently has no effect on pepsin secretion in the calf (Bell \& Razig, I973).

The control diet was fed within the Latin square design primarily to check whether the secretory activity of the pouches deteriorated with age. Results for calf 6 indicated a trend which suggested some deterioration in protease secretion, but there were no correlations between mean values for the different protein sources and those for the control diet for any characteristic of pouch secretion which was measured. Therefore the use of a control diet in the experimental design did not permit increased precision in comparisons between the experimental diets.

The patterns of $\mathrm{pH}$, volume, total titratable acid secretion and protease secretion from the pouches in relation to feeding agreed with published findings (Ash, 1964; Hill, Noakes \& Lowe, 1970). The inverse relationship between $\mathrm{pH}$ and flow-rate indicated a direct relationship between free $\mathrm{H}^{+}$concentration in gastric juice and its flow-rate whereas the concentration of protease was inversely related to flow-rate. As a consequence titratable acid secretion was directly and protease secretion inversely related to flow-rate.

The $\mathrm{pH} v$. proteolytic activity curves clearly indicate that digesta fluid, or pouch 
secretion, may be used to determine whether pepsin or rennin activity is dominant at a particular age (Henschel, Hill \& Porter, 196r; Hill et al. 1970; Henschel, 1973). Irrespective of age, all calves from which pouch secretions were obtained (the youngest age at sampling was $20 \mathrm{~d}$ ) had much greater activity at $\mathrm{pH} 2 \cdot \mathrm{I}$ than at $\mathrm{pH} 3 \cdot 5$. Moreover, when the results from all calves were considered, a decrease with age occurred in activity at $\mathrm{pH}_{3.5}$ but not at $\mathrm{pH} 2 . \mathrm{I}$ in response to the control diet, which indicates that rennin secretion in the calves decreased with age (Henschel et al. 1961).

The results indicate that the digesta from calves given diet MHM were more acid I- $3 \mathrm{~h}$ after feeding than digesta from calves given diet SHM. There was also a tendency for a greater output of acid by the pouches when calves were given diet MHM. Tagari \& Roy (1969) concluded from a study of pyloric outflow that MHM probably stimulated greater acid secretion than SHM did. Ternouth et al. (1974), from measurements of $\mathrm{Cl}^{-}$minus $\mathrm{Na}^{+}$in the duodenal outflow, concluded that there was about II \% greater acid secretion with MHM. Our results support these conclusions.

Slightly more acid appeared to be secreted by the pouches when the calves were given diet FPC than when they were given diet MHM. However as diet FPC, in contrast to diet MHM, did not clot, gastric secretions would have been free to mix with much more of the diet in the abomasum. This was reflected in the higher $\mathrm{pH}$ and lower titratable acidity of the digesta from diet FPC. Diet SF was a less effective stimulant to acid secretion than diets FPC or MHM. Ternouth (I97I) found that when $40 \%$ of MHM was replaced by FPC or SF, the $\mathrm{pH}$ of the duodenal effluent of calves given $\mathrm{SF}$ was more alkaline during the first $4 \mathrm{~h}$ after feeding than that of the effluent from calves given FPC or MHM. Thus FPC appears to provide a better stimulus than SF to gastric acid secretion. This cannot be explained by any great difference in the ratio, undigested:digested protein the duodenal fluid (Ternouth et al. 1975) but it may result from differences in the products of protein degradation. Hill (rg68), however, has pointed out that there is no direct evidence available on dietary factors which stimulate gastrin production and release in ruminants.

The relative buffering capacities of the digesta fluids relating to the four diets fed in Expt I suggest that the $\mathrm{pH}$ of digesta obtained after giving diet $\mathrm{SF}$ would have been even higher relative to the other three diets if the digesta from diet SF had had a better capacity to buffer gastric acid (Table 2).

Diet SF produced much less protease activity at $\mathrm{pH} 2 \cdot \mathrm{I}$ than the other three diets. Diet MHM produced more activity than diet FPC and the value for diet SHM was much lower than for diet MHM but not significantly so.

Diet MHM stimulated considerable acid and the greatest protease secretion; diet FPC produced more acid but less protease secretion. As the FPC diet did not clot, it might be inferred that protease secretion is, at least in part, a response to the retention time of DM in the abomasum (Ternouth, 197I) or to the physical nature of the clot, which influences gastric secretory reflexes. Cholinergic reflexes stimulate acid secretion directly by acting on the parietal cells, or indirectly by facilitating gastrin secretion and potentiating its effect on parietal cells (Debas, Konturek, Walsh \& Grossman, 1974). The peptic chief cells appear to respond primarily to direct cholinergic neural stimulation, although gastrin is also implicated (Gregory, 1974). 
It is concluded that the protein sources which are used in milk-substitute diets vary in their ability to stimulate abomasal acid and pepsin-rennin secretion. J. H. B. Roy, I. J. F. Stobo, S. M. Shotton, P. Ganderton, C. M. Gillies \& A. Turvey (unpublished results) have found the clear superiority of a diet containing MHM over those in which 40 or $70 \%$ of the milk protein has been replaced by FPC or SF, in producing live weight gain in preruminant calves up to $13^{-1} 5$ weeks of age. Moreover, at 4-Io weeks of age, digestibility of protein was greater for FPC than for SF. Thus calf performance may be a reflexion of the stimulation given to gastric secretion by the different sources of protein.

We wish to thank Dr H. L. Buttle for performing the surgery, members of the Calf Section of the Feeding and Metabolism Department, NIRD for their cheerful assistance, Dr C. C. Balch for having one of us (V.J.W.) as a visitor, and the University of New England for granting Study Leave to V.J.W.

\section{REFERENCES}

Anson, M. L. (1938). F. gen. Physiol. 22, 79.

Ash, R. W. (196r). F. Physiol., Lond. 157, 185.

Ash, R. W. (1964). F. Physiol., Lond. 172, 425.

Bell, F. R. \& Razig, S. A. D. (1973). F. Physiol., Lond. 228, 499.

Debas, H. T., Konturek, S. J., Walsh, J. H. \& Grossman, M. I. (1974). Gastroenterology 66, 526.

Espe, D. L. \& Cannon, C. Y. (1935). Y. Dairy Sci. 18, 14I.

Gregory, R. A. (1974). F. Physiol., Lond. 241, 1.

Henschel, M. J. (1973). Br. F. Nutr. 30, 285 .

Henschel, M. J., Hill, W. B. \& Porter, J. W. G. (1961). Proc. Nutr. Soc. 20, xl.

Hill, K. J. (1968). In Handbook of Physiology. Section 6: Alimentary Canal, vol. 5, p. 2747 [C. F. Code, editor]. Washington, DC: American Physiological Society.

Hill, K. J. \& Gregory, R. A. (I95I). Vet. Rec. 63, 647.

Hill, K. J., Noakes, D. E. \& Lowe, R. A. (1970). In Physiology of Digestion and Metabolism in the Ruminant, p. I66 [A. T. Phillipson, editor]. Newcastle upon Tyne: Oriel Press.

Mylrea, P. J. (1966). Res. vet. Sci. 7, 333.

Shillam, K. W. G., Roy, J. H. B. \& Ingram, P. L. (1962), Br. F. Nutr. x6, 585.

Singleton, A. G. (195I). F. Physiol., Lond. 115, 73P.

Tagari, H. \& Roy, J. H. B. (1969). Br. F. Nutr. 23, 763.

Ternouth, J. H. (I97I). Studies on the role of the abomasum and pancreas in digestion in the young calf. PhD Thesis, University of Reading.

Ternouth, J. H., Roy, J. H. B. \& Siddons, R. C. (1974). Br. F. Nutr. 3r, I3.

Ternouth, J. H., Roy, J. H. B., 'Thompson, S. Y., Toothill, J., Gillies, C. M. \& Edwards-Webb, D. J. (1975). Br. F. Nutr. 33, 13 I.

Whitehorn, J. C. (1921). F. biol. Chem. $45,449$.

Yates, F. (1933). Emp. F. exp. Agric. I, 129. 